\title{
A Philosophical Analysis of Emergent Issues in Art, Religion and Culture for Educational Development in Africa
}

\author{
Anselm Adodo ${ }^{1}$, Paul Jackson Ireyefoju ${ }^{2}$, Benedicta Ehi Momodu ${ }^{3}$ \\ ${ }^{1}$ University of Ibadan, Institute of African Studies, Ibadan, Nigeria \\ ${ }^{2}$ College of Education, Department of Educational Foundations, Warri, Nigeria \\ ${ }^{3}$ Federal College of Education (Technical), Department of Educational Foundations, Asaba, Nigeria \\ *Corresponding Author: Anselm Adodo, University of Ibadan, Institute of African Studies, Ibadan, \\ Nigeria
}

\begin{abstract}
One of the major philosophical challenges emerging from the issue of art, religion and culture in Africa is the relegation of the essential attributes which constitute them. And the adoption of a strange civilization in their places seems to make the African learner a confused being. Unfortunately, the African learner becomes a victim of miseducation because the education offered has little or no bearing on the African worldview. The purpose of this paper is to attempt a philosophical examination of the emergent issues arising from art, religion and culture, and how education can help to resolving them in order to train the mind so that he can understand the world around him. This is against the belief that with education the human mind is capable of transcending the issues which becloud the reality of the African worldview. What impact, then, can education make in the development and promotion of art, religion and culture in Africa? Because the dimensions of education are ubiquitous, covering every aspect of human endeavour, it was presupposed that education needs to take into consideration the nature of our being and existence, in order to build and maintain the qualities which make man human, have sense of cooperation, togetherness and belongingness, as well as free the mind from unverified belief. This is because the uniqueness of a people is inherent in art, religion and culture. African philosophical approach was adopted in examining the emergent philosophical issues surrounding the totality of the African continent.
\end{abstract}

Keywords: Emergent philosophical issues; art, religion and culture; educational development; African philosophy; Africanism

\section{INTRODUCTION}

The purpose of this paper is to attempt a philosophical examination of the emergent issues arising from art, religion and culture, and how education can help to resolving them in order to train the human mind towards the understanding of the world around him. This is against the belief that with education the human mind is capable of transcending the issues which becloud the reality of the African worldview. One of the major philosophical challenges emerging from the issue of art, religion and culture in Africa is the relegation of the essential attributes which constitute the African worldview. And the adoption of a strange civilization in their places seems to make the African mind a confused being. Unfortunately, the African learner becomes a victim of miseducation because the education offered has little or no bearing on the African (weltanschauung) worldview. Temple (cited in Ukagba, 2003) believes that the reason for this arises from irrelevance, thus he says:

"If it is a crime against education to impose on human race a civilization devoid of philosophy, devoid of practical wisdom and of spiritual aspiration, it would be and even more serious crime to deprive a people of its own patrimony, of an heritage which alone can ensure their full human quality, of the only good which can serve as the starting-point for cultural development" (p. 119).

On the issue of patrimony and its importance to a people's worldview, Oakeshott (1967) says "every man is born an heir into an inheritance of human achievements which include among others, an inheritance of thoughts, emotions, feelings, images, visions, beliefs, language, relationships, organizations, utensils, arts and books, rituals, skills, values, intellectual and practical enterprises, procedures, canons and maxims of conduct." He went further to add that "a people also provide 
meaning and interpretation to their world, a world of fact, of expressions which have meanings and require to be understood because they are not only the expression of human minds, they also point at how a people perceive the world." Consequently, according to Oakeshott (1967), "there is no other way for a human being to make the most of himself than by learning to recognize himself in the mirror of his inheritance."

Prior to colonialism, African traditional values such as dignity in labour, concern for one another, tolerance, cooperation, compromise, belongingness, brotherhood, oneness, respect for life, hospitality, solidarity, togetherness, deep religiosity, dialogue and communication, openness and frankness in socio-political affairs form part of the African core values. These core values, according to Nwankwor (2003), are what African philosophy refurbished so that what we truly are is not submerged by Western culture. Unfortunately, one of the negative consequences of our contact with the West has been the importation into Africa of a value system which is foreign to the traditional African (Ukagba, 2003). The elements of culture, art and religion, which define a people and give them their specific outlook, are the most influenced. And "the self which is not a rational abstraction but a historic personality was confronted by the challenges of the time: persuasion, compulsion, and permissive tendency, among others" (Ukagba, 2003). The materialistic tendency of the Western world creates a sense of individualism which erodes the collective aspirations which unite the people.

In the course of providing meanings and interpretations to the African world, the African seems to do things base on Western epistemology and reality. This is not good for the individual self and Africa because we cannot continue to see ourselves and analyze our world from Western perspective. What impact, then, can education make in the development and promotion of art, religion and culture education in Africa? Put differently, if education is relevant to the African inheritance, the human mind, most probably, is capable of transcending the natural attitude which beclouds the reality of the African worldview. On this premise, it was presumed that African philosophy, as an approach, is adopted as the nexus that would provide the necessary ingredients for the African mind to realize himself as an African with possibility to make the difference in the face of emerging philosophical issues in the area of art, religion and culture. It is hoped that this paper will point out the need why any education system in Africa deserves an African philosophical foundation, and the need to look inward for strength and determination to make the difference.

\section{Clarification Of Key Concepts}

\subsection{Educational development}

Educational development was described by Nwankwor (2003) as holistic all round development aimed at elevating man from the animal kingdom to the rational sphere. According to him, it is a foresighted and progressive development that can bring about the betterment of the lot of human persons, particularly in Africa. The dimensions of educational development, according to Nwankwor (2003), are ubiquitous and it cut across social, cultural, economic, political, religious, intellectual, scientific and technological aspects of human enterprise. In an educationally developed environment, the human specie are beings endowed with powers of reason, sense perception and self-determination. They are beings who possess the power of making symbols, thereby creating the human word which enables them to socially create their world, make tools to produce goods and services, conserve and promote the environment of their beings and existence (Njoku, 2002). The need for educational development in Africa is to realize the self within the context of his inheritance as a being capable of contributing to the social brain (a network of individual minds working on ideas and propositions about how to survive in a world that must be conquered and made more habitable), well-being and welfare of humanity (Omatseye, 2004).

\subsection{Art}

Art is defined in the Oxford Dictionary of English as (1) the expression or application of human creative skill and imagination; typically in a visual form such as painting or sculpture, producing works to be appreciated primarily for their beauty or emotional power; works produce by such skill and imagination; creative activity resulting in the production of painting, drawing, or sculpture. It also defines it as (2) the various branches of creative activity such as music, drama, literature, painting, and dance. Art is also defined (3) as subjects of study primarily concerned with human creativity and 
social life, such as languages, literature, and history (as contrasted with scientific or technical subjects). It is also defined (4) as a skill at doing a specified thing typically one acquired through practice. These expressions of art reveal that art is not a prerogative of any particular people. Africans also participate in every aspect or sense the word art was used.

\subsection{Religion}

According to Omoregbe (2007), is derived from three Latin words as its root, "Ligare" which means bind, "Relege" meaning to unite, or to link and "Religio" means relationships. From this etymological definition, Omoregbe (2007) says religion is essentially a relationship, a link established between two persons, the human person and the divine person believed to exist. It is something that links or unites man with a transcendent being, a deity, believed to exist and worshipped by man. According to Omoregbe (2007), whether such a being exists, or simply the figment of the imagination of the religious man, is not important to the concept of religion, as long as the deity is really believed by the religious man to exist. As means of reconciling human person and the divine person, Bamisaiye (1990) defines religion as human effort to reconcile himself with cosmic forces which he believes to be capable of influencing his fate, positively or negatively. Miller (cited in Bamisaiye, 1990) from a functionalist perspective defines religion as the effort to bring together all the disparate and even contradictory fragments of life so as to articulate the mystery of their mutual dependence...symbolizes the coincidentia oppositorum of life and death, of heaven and hell, of freedom and necessity, of sin and spirit, of goodness and evil, of suffering and salvation, of body and mind (p.66).

The contradictory and the mutual dependence of the duality of things in nature create in man a differing sense of religion, which makes the phenomenon a different thing to different people. However, religion is still a fascinating and interesting phenomenon in human existence that cannot be ignored. Some individuals have little or nothing to do with religion, but for others religion influences the way they think, perceive things, behave and conduct themselves in the community.

For instance, in the Nigerian situation, religion is at one time social and spiritual. While religious adherents are usually identifiable by the various garbs of their article of faith, the doctrines of their religions are emphasized more than the social relevance of the various faiths (Bamisaiye, 1990). This seems to be the root of all religious crises and bigotry in the continent. In our everyday life experiences, we understand too that there are people whose religious life is different from their social life and there are people whose religious life style cannot be separated from their social life style. These differences, as it seems, may have culminated into different revealed religions of the world which include among others, African religion, Christianity, Islam, Eastern religion and Judaism. The first three are the dominant religions in Africa. There are also conflicting theories associated with religion, like monotheism (one God), pantheism (God is identical with nature), polytheism (many gods), and atheism (denial of God).

\subsection{Culture}

Culture has been variously defined by anthropologists in many ways. But many modern conceptions of culture are based on the work of Taylor (1871), who defines culture as that complex whole which includes knowledge, beliefs, art, morals, laws, customs, and other capacities and habits acquired by man as a member of society. This definition is all-embracing because it includes almost everything about a people - their thoughts about the world, their beliefs about how people should live, their actions and all that is required in the course of growing up in a particular society (Peoples and Bailey, 1994). Ralph Linton (cited in Peoples and Bailey, 1994), defines culture as the sum total of knowledge, attitudes, and habitual behaviour patterns shared and transmitted by members of a particular society. This definition reveals that culture is something we all learned and shared as a people. What we learned and shared also include the mental aspect of culture such as thoughts, feelings, knowledge, and attitude which exist in the human mind. And our habitual behaviour patterns, that is, how people act and conduct themselves in various situations is the practical aspect of what happens in consciousness. And what happens in consciousness is influenced by our gene, awareness, experience, values, attitudes, degree of knowledge and skills acquired in the course of growing up in a giving human setting. 


\section{African Philosophy as Procedure For Educational DeVelopment In Africa}

The reason for this choice of methodology is to make the African learner appreciate his being and the African environment in order for him to have a sense of belongingness. This is because, even though educational principles are universal, its practices are socially determined and culturally based. The essence of African philosophy, according to Nwankwor (2003) and Okolo (1998), is to foster the environment of African existence and reconcile the African learner with his natural inclination for the transcendence. Through this mode, the African learner embarks upon self-knowledge, the knowledge of the African world and reality in a most profound and comprehensive manner. Amongst many issues, this procedure of methodology raises deep critical questions about the African as a being-initself, a being-in-the world, the African Life-force, culture and experiences. Consideration was also given to traditional African values such as concern, tolerance, cooperation, compromise, belongingness, brotherhood, oneness, respect for life, hospitality, solidarity, togetherness, deep religiosity, dialogue and communication, openness and frankness in socio-political affairs as basis for educational development. In our analysis of culture, art and religion, several philosophical issues which have either separate or alienate the African learner were given consideration. So that in reconciling the learner with the environment the learner as well as Africa is ennobled, dignified and humanized (Okolo, 1998). This paper also critiques the African values, life options, social goals, collective pursuits and ways of life.

\section{Some Emergent Philosophical ISSues For Educational DeVelopment In Africa}

African art includes paintings, ceramics, sculpture and statues, graphical designs, aesthetic styles and cultural values. Art and aesthetics are essential aspects of human culture. They are the distinguishing features which separate a people from other peoples. African art and aesthetic styles and values tell much about Africans. For instance, the Festival of Art and Culture, tagged Festac 77, held in Nigeria was a demonstration of the rich qualities of African heritage - art, aesthetic values and culture. Proverbs, music, drama and dance, language, folktales, African prose and poetry, human actions and reactions, among others are some elements that further reveal the rich cultural heritage of human achievements. The emergent philosophical issue here is that the African learner, like other Africans, seems not to have regard for certain aspects of his art and the artist themselves. Our art, grooves, hills and mountains, forests, rivers and streams are seen as centres of idolatry, evil and fetishism. African artists and custodians of African art such as the priests and traditional practitioners are treated as such in their homes because of the present religious, social, economic and political climates. In contemporary African society, herbs and medicinal root and wood are also considered as evil and devilish. However, Africans do not see anything wrong in consuming alternative drugs imported from Asian and European countries.

As a result of this ugly situation, some of the artists and custodian of African heritage lack the confidence to establish themselves at home. Consequent upon this, some of them adopt the "do nothing, be nothing approach" and those who adopt the radical approach are sometimes thrown into prisons, or forced into exile, or withdrawn into their shells. With this ugly scenario, according to Nwankwor (2003), we lose our best brains and materials to the world around us, as a result of lack of motivation, encouragement and patronage. Through these African artists in diaspora, we have come to realize the worth of things in our environment. They make our textile and metal art to be invaluable elsewhere and people back home in Africa followed their ingenuity. Art is a source of job creation for the young ones in Africa. The function of education, according to (Nwankwor, 2003), is to create awareness on the implication of such experience on the educational achievement of Africa and Africans.

Our environmental and geographical features are also sources of tourism and economic development. On religious ground some of these features can be places where religious men go to for spiritual realization or development. They are also sources of national identity associated with a people's way of perceiving the world around them. It is true that Africans believe in forces, but for any of these places to be associated with evil, it is human thinking that makes it so. Geographical and environmental features are nothing in themselves. This is because they are disembodied beings. For them to be active and potent, it is man that discovers and makes use of their essential elements to achieve human goals or purposes. It is time we demystify these places and give them their proper 
roles in society.

Religion as a belief in a divine or superhuman power or powers to be obeyed and worshipped as the creator of the universe, transcendental and immanent which ought to bind human beings together, sometimes turn brothers, family members apart in Africa (Omoregbe, 2007). Most countries in Africa, and elsewhere around the world, are either divided alone religious lines or religious sects. If religion which is supposed to transform the individual adherent to the extent that he lives in peace, unity, harmony with himself, neighbours, environment and God fails to do so, it means that it is either the people cannot go beyond the doctrinal aspect of their religions, or the concept of religion is misunderstood in its practical and humanistic senses. Onimhawo and Izibili (2004) point to this misconception when they say that the true nature of Islam and Christianity was not given to the African, rather it was the dreg, tissues of these religions the African is indoctrinated with.

Another issue is the proliferation of religious sects in Africa (Nwankwor, 2003). With emphasis on Christianity, Mbiti (1991) says that the major problem confronting Christianity in Africa is the divisions, sects, denominations, and the difficulty to give the religion an African character. "This foreignness, according to him, "is a drawback because it means that Christianity is kept on the surface and is not free to deepen its influence in all areas of African life and problems." Another reason is that traditional believers and their priests tend to hide their identity since western education has always painted African religion as barbaric and heathen. Most Africans, particularly Nigerians, publicly profess faith in Islam or Christianity more as a public relation strategy than a matter of conviction and it could be one of the reasons African religion is not recognized.

In spite of this trend, the ethical, moral and spiritual emphasis of the religions in Africa can still bring about unity, togetherness, sense of belongingness, solidarity in Africa, especially if given the background of multiculturalism and ethnic affiliations in the continent. The different religion in Africa could achieve this goal, if and only if, they give a better understanding and interpretation of the African universe and milieu (Nwankwor, 2003). This is because the understanding of the African situation and the application of the principles of these religions would proffer satisfactory answers to some of the psychological, sociological, historical, religious, economic, cultural, scientific and technological problems bedevilling the African world.

Another emergent philosophical issue for educational development in Africa is the traditional thought system. The traditional African thought system has no way of reducing what can be known and how they can be known in purely empirical epistemological sense (Ekanola, 2006). Empirical epistemology is associated with observation, experimentation, collection of data for the purpose of analysis and conclusion. Africans believe in life force which is rooted in interrelationship of all extent into one massive chain called reality (Onimhanwo and Izibili, 2004 and Ozumba, 1994). Reality is the perception of the world from a cultural standpoint associated with a people. In viewing their world, they seem not to differentiate the social from the spiritual because to them the spiritual is fundamentally the origin and foundation for the social, and every other aspects of life. A deviation from this socio-spiritual structure is usually greeted with moral sanctions, which also serve as deterrent to others. Further consequence of this socio-spiritual structure, or forces upon social (interaction) relationship, is that it seems to encourage absolute dependence on significant-order, or other-directed, which does not promote critical outlook and self-realization in the African learner.

In this regard, the task of education is that, even though the African procedure for determining truth is appropriate, there are other ways of realizing what truth is. And education ought to make the African learner benefit from them, by pointing out the strength and weakness of each epistemological approach to knowing. Another function of education is to free the mind from the notion that there is divine hierarchy in the order of the world. This is because social structures are not divine, but manmade. And man is free to the extent to which his potential can carry him to discover his possibilities. In other words, if God does not create some people significant and others insignificant, it follows that if the learner is given an education that would enable him realize himself and confront the existential situations of the environment he can therefore be in the right frame of mind to make the difference we all desired in Africa.

Some of the crucial submissions reached in this paper are: (a) culture, religion and art are sources of uniqueness and identity. But for the permissive trait of man, particularly the African makes his contact 
with other civilizations worrisome. Contact with other culture ought to improve areas of deficiency, not to destroy the African self and environment. (b) Art is a source of job creation and generating income for the economy. Because every aspect of art can be learned in and outside the school environment, it makes it more reasonable for the African learner to explore this area of interest. It is something one can pick-up as a career, irrespective of one's educational background. (c) Education is the means through which the African learner, and other Africans, can realize his being and protect his inheritance. This is because the process of educating is a function of time and space. So making education meaningful and realistic to the African learner is to bring to the fore the uniqueness of the African peoples.

\section{IMPLiCATIONS FOR EDUCATION POLICY}

There is no gainsaying the fact that education is a necessary magic-wand for individual and society's development around the world. African states, particularly Nigeria, intend to use education as instrument par excellence. This intention is expressed in FRN (2004) as government policy on education: what it intends to achieve with education on the long run. Bamisaiye (1989) believes that this intention can be realized through our understanding of what the country hopes to achieve with the National Policy on Education. It is with this understanding this paper was anchored on the cultivation of the right type of attitudes, values, skills and knowledge for the development of the individual learner and society. Educational development in Africa is to make the self recognize himself as a historical personality defined by social interactions and human consciousness as products of cultural heritage and environment. It is when the learner is proud of himself, understands the social happenings, geographical or environmental conditions of his place that the sense of national consciousness is realized. Thereafter, the self can now develop the right type of knowledge, skills, values and attitudes which will enable him think of survival in the African environment and elsewhere.

Surviving in the African environment will demand education to provide the learner with both theoretical and practical knowledge. It is hoped that if this is done it will turn the learner into a problem-solver, rather than an individual who recognizes his problems but lacks the "capacity" and "will" to resolve them. This claim reveals that the African learner must be humble, respectful, and satisfied with himself, his choice of job and environment. And everyone around him must appreciate him as a person, in his own right, capable of contributing to the economy, others' welfare and wellbeing of society. This sense of duty, belongingness and appreciation shows that no person or work is useless. This is because everyone has the right to choose any job or service he wishes to offer, as long as it is legitimate and within the limit of legal practices. And all we need to do is to encourage ourselves to be committed to our choices and be responsible for our actions and reactions. Although, this may not be practicable at all time, it is believed that such encouragement would make the learner to be proactive and capable of matching human (internal) potentials with available resources in the environment.

\section{CONCLUSION AND RECOMMENDATIONS}

It is the African with a sense of purpose, sense of belongingness, and the capacity to interpret and provide meaning to the existential challenges confronting the African environment that can possibly make use of education as a tool for social reconstruction for the betterment of himself and society. Educational development is to enable the learner look inward so that he can realize the self as an historical personality with the "will" and "commitment" to make the difference as an individual and a citizen. It was therefore recommended that education should develop critical outlook in the African learner so that he can examine the uniqueness of African culture, art and religion for the purpose of exhuming its beauty and quality. The celebration of cultural activities in schools and colleges should not be allowed to promote ethnicity and cultural superiority. Rather they should showcase the richness of our cultural heritage and need for coexistence in a multicultural society. Religious fora in schools and colleges should be geared towards sense of duty, tolerance, peaceful coexistence, self-discipline and patriotism in order to encourage and promote the right type of knowledge, skills, values and attitudes in the African learner. The place of culture, art and religion in educational development is in a sense to showcase what the African is capable of bringing to the global stage. And if we claim there is abundance of talents in every area of human endeavour, education should, then, allow the African 

in Africa

to free himself from his natural attitude (superstition, presupposition, belief among others) in order to discover his potentials and possibilities so that he too can be a contributor at the global stage. This is because every individual is an actor and whatever situation or condition a human actor finds himself he is a possible possibility.

\section{REFERENCES}

[1] Bamisaiye, R. (1990). Sociological foundations of Nigerian education: An introduction. Agoyi, Ibadan: AMD Publishers.

[2] Bamisaiye, R. (1989). A practical approach to philosophy of education. Agoyi, Ibadan: AMD Publishers.

[3] Ekanola, A.B. (2006). Metaphysical issues in African philosophy. In O. Oladipo (Ed.), Core issues in African philosophy. (pp. 23 - 27). Ibadan: Hope Publications.

[4] Federal Republic of Nigeria (2004). National policy on education. Lagos: NERC Press.

[5] Mbiti, J.S. (199). Introduction to African religion. Ibadan: Heinemann Educational Book (Nigeria) Limited.

[6] Njoku, F.O.C. (2002). Philosophy in politics, law and democracy. Owerri: Claretian Institute of Philosophy in collaboration with Claretian Communications.

[7] Nwankwor, I.S.J. (2003). The philosopher and the challenges of educational development in Africa. Ogirisi: A New Journal of African Studies, 1(1), 108 - 118.

[8] Oakeshott, M. (1967). Learning and teaching: In R.S. Peters (Ed.), The concept of education. London and Henley: Routledge and Kegan Paul.

[9] Okolo, C.B. (1998). African philosophy and public life: A socio-political perspective. In J.O.

[10] Oguejiofor (Ed.), African philosophy and public affairs. (pp.7 - 15). Port Harcourt: Delta Publications (Nigeria) Limited.

[11] Omatseye, J.N. (2004). Educational philosophy for African schools. Benin City: Mindex Publishers.

[12] Omoregbe, J. (2007). A philosophical look at religion: Philosophy of religion. Lagos: Joja Educational Research and publishers Limited.

[13] Onimhanwo, J.A and Izibili, M.A. (2004). An introduction to Eastern philosophy. Benin City: EverBlessed publishers.

[14] Osokoya, I.O. (2010). History and policy of Nigerian education in world perspective. (revd ed.). Ibadan: Laurel Educational Publishers Limited.

[15] Oxford Dictionary of English (2005). Second Edition, Revised. Oxford: Oxford University Press.

[16] Peoples, J and Bailey, G. (1994). Humanity: An introduction to cultural anthropology. ( ${ }^{\text {rd }}$ ed.). New York: West Publishing Company.

[17] Tylor, E.B. (1871). Primitive culture. London: J. Murray.

[18] Ukagba, G.U. (2003). African philosophy as bedrock for African development. Ogirisi: A New Journal of African Studies, 1(1), 119 - 130.

\section{AUTHORS' BIOGRAPHY}

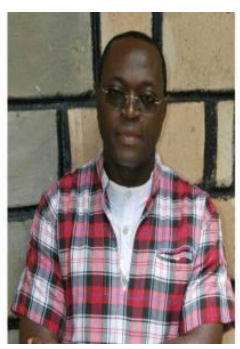

Anselm Adodo (Ph.D.) is Director and Lead researcher at Pax Integral Research and Development Initiative (OFIRDI), Nigeria, and a visiting lecturer in African Transformation Studies at Institute of African Studies, University of Ibadan, Nigeria. His research areas are: African Ontology, Integral Research, Sociology of health and illness behaviour, Transformative Economics and Educational Transformation in Africa. His latest book is titled, Integral Community Enterprise in Africa. Communitalism as an Alternative to Capitalism' (Routledge, 2017). He is a Senior Fellow at Trans4m centre for Integral Development, Geneva, Switzerland.

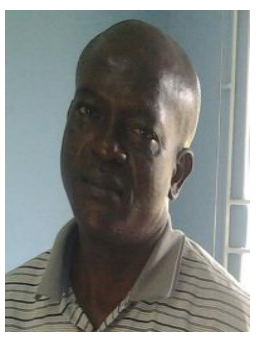

Paul Ireyefoju (Ph.D.) is a lecturer in Educational Foundations at College of Education, Warri, Nigeria. His teaching and research interest are in Educational Philosophy, with special interest in adolescence education and existential phenomenology. He is a member of Philosophy of Education Association of Nigeria (PEAN). 

in Africa

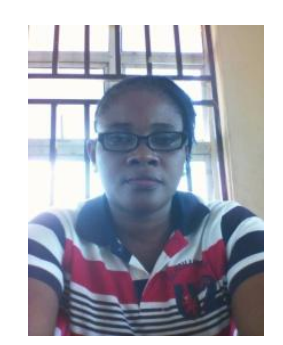

Benedicta Momodu teaches Philosophy of Education at Federal College of Education (Technical), Asaba, Delta State, Nigeria. She is alumni of University of Benin, Benin City, Nigeria. Her research areas include child-girl education, psychomotor education and curriculum studies.

Citation: Anselm Adodo, Paul Jackson Ireyefoju, Benedicta Ehi Momodu. "A Philosophical Analysis of Emergent Issues in Art, Religion and Culture for Educational Development in Africa". International Journal of Humanities Social Sciences and Education (IJHSSE), vol 5, no. 1, 2018, pp. 127-134 doi: http://dx.doi.org/10.20431/2349-0381.501020.

Copyright: (C) 2018 Authors. This is an open-access article distributed under the terms of the Creative Commons Attribution License, which permits unrestricted use, distribution, and reproduction in any medium, provided the original author and source are credited. 